\title{
CYANOBACTERIAL BIODIVERSITY FROM DIFFERENT FRESHWATER PONDS OF THANJAVUR, TAMILNADU (INDIA)
}

\author{
Chinnasamy MUTHUKUMAR ${ }^{1}$, Gangatharan MURALITHARAN ${ }^{1}$, \\ Ramasamy VIJAYAKUMAR ${ }^{2}$, \\ Annamalai PANNEERSELVAM ${ }^{2}$ and Nooruddin THAJUDDIN ${ }^{1 *}$ \\ ${ }^{1}$ Department of Microbiology \\ National Facility for Marine Cyanobacteria \\ Bharathidasan University, Tiruchirappalli - 620024 , India. \\ ${ }^{2} \mathrm{P}$. G. and Research Department of Botany and Microbiology \\ A.V.V.M. Sri Pushpam College (Autonomous) \\ Poondi - 613 503, Thanjavur District, Tamil Nadu, India. \\ *Corresponding author: nthaju2002@yahoo.com
}

Recibido el 24 de julio de 2006, aceptado para su publicación el 11 de enero de 2007 Publicado "on line" en febrero de 2007

\begin{abstract}
Cyanobacterial biodiversity from different freshwater ponds of Thanjavur, Tamilnadu (India). Studies on the cyanobacterial biodiversity of 5 different freshwater ponds in and around Thanjavur, Tamilnadu during summer month (June, 2004) has been made and compared their variations among five different ponds. In addition, certain physico-chemical parameters of pond waters such as dissolved oxygen, net productivity, $\mathrm{pH}$, carbonate, bicarbonate, nitrate, nitrite, total phosphorus, inorganic phosphorus etc. were also analyzed and statistically compared with the cyanobacterial diversity. Totally 39 species of 20 genera of cyanobacteria were recorded in all 5 different ponds. Only 6 species of cyanobacteria were identified in Pond 1 (Dabeerkulam), where a massive bloom of Microcystis aeruginosa was recorded, which had a significant effect in reducing the other cyanobacterial population. As many as five species namely Aphanothece microscopica, Synechocystis aquatilis, Merismopedia glauca, Oscillatoria limnetica and O. subbrevis were common in all the ponds surveyed except in Pond 1.
\end{abstract}

Key words. Biodiversity, ecosystem, cyanobacteria, Oscillatoria, Microcystis.

RESUMEN. Biodiversidad de cianobacterias en diferentes charcas de agua dulce de Thanjavur, Tamilnadu (India). Se ha inventariado, y comparado entre sí, la biodiversidad de cianobacterias de 5 charcas de agua dulce de Thanjavur, Tamilnadu (India); el estudio se llevó a cabo en junio de 2004. En paralelo, también se determinaron los valores de ciertos parámetros físico-químicos que podrían explicar las variaciones en los valores de biodiversidad: oxígeno disuelto, productividad neta, $\mathrm{pH}$, carbonato, bicarbonato, nitrato, nitrito, fósforo total, fósforo inorgánico, etc. Un total de 39 especies de 20 géneros de cianobacterias se identificaron entre las 5 charcas. En la charca 1 (Dabeerkulam) se detectaron 6 especies, pero cuando tuvo lugar una flor de agua de Microcystis aeruginosa las restantes especies apenas se pudieron detectar. Cinco especies (Aphanothece microscopica, Synechocystis aquatilis, Merismopedia glauca, Oscillatoria limnetica y $O$. subbrevis fueron comunes en todas las charcas con excepción de la número 1.

Palabras clave. Biodiversidad, cianobacterias, ecosistema, Oscillatoria, Microcystis. 


\section{INTRODUCTION}

Cyanobacteria (blue-green algae) are capable of both carbon assimilation and $\mathrm{N}_{-}$ fixation, thereby enhancing productivity in variety of environments. Apart from fixing atmospheric $\mathrm{N}_{2}$, they secrete a number of biologically active substances. Tropical conditions such as those in India provide favourable environment for the luxuriant growth of these organisms in the natural ecosystems such as different types of soil, freshwater bodies, oceans, saline backwaters, estuaries, and also hyper saline saltpans (Subbaramaiah, 1972; Srivastava \& Odhwani, 1992; Thajuddin \& Subramanian, 1992; Thajuddin et al. 2002; Rajkumar, 2004 and Chellappa et al. 2004).

Cyanobacteria, until recently in oblivion, uncared for and unrecognized, have shot into fame and popularity owing to a host of their innate properties that make them ideal organisms for use in a variety of ways to meet our needs and to promise us a bright future (Thajuddin and Subramanian, 2005). Besides their ecological significance, offer a grate potential tool as an organisms for the biotechnological interest such as mariculture, food, feed, fuel, fertilizer, medicine and combating pollution (De, 1939; Mitsui et al. 1981; Venkataraman 1981, Venkataraman, 1983; Kannaiyan, 1985; Borowitzka, 1988; Gustafson et al., 1989; Prabaharan \& Subramanian, 1995; Subramanian \& Uma, 1996). The present work was carried out to understand the diversity of cyanobacteria from five different freshwater ponds of Thanjavur District, Tamilnadu as an initiative study for exploiting their innate potentials.

\section{MATERIAL AND METHODS}

\section{Study area and sampling}

Thanjavur is located in the centre-east of Tamil Nadu state, India (Lat. $10^{\circ} 47^{\prime} \mathrm{N}$; Long. $\left.79^{\circ} 10^{\prime} \mathrm{N}\right)$. Thanjavur district occupies $3,205 \mathrm{sq}$ miles $[8,300 \mathrm{sq} \mathrm{km}]$ in area in the part of flat, fertile Cauvery Delta region, which is one of the most important ricegrowing areas in India. There are several natural and artificial (temple) fresh water ponds are distributed more frequently in and

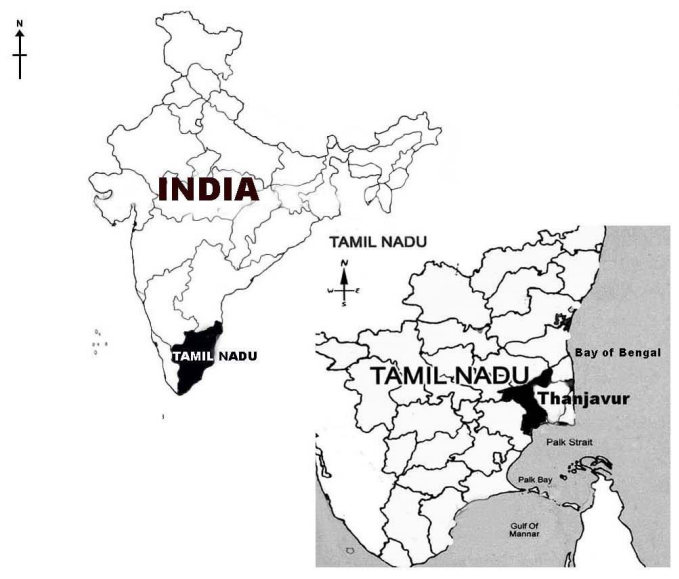

1 - Pond 1 (Dabeerkulam)

2 - Pond 2 (Mariyamman Kovil)

3 - Pond 3 (Padithurai)

4 - Pond 4 (Pulavarnatham)

5 - Pond 5 (Sivalingam temple)

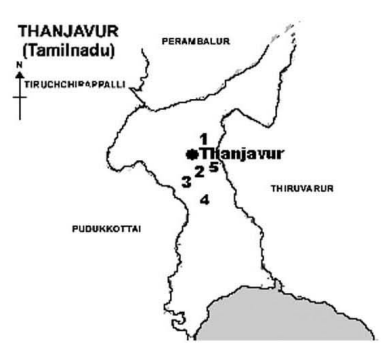

Fig. 1. Map showing the locations of 5 different ponds in Thanjavur. Localización geográfica de las 5 charcas en Thanjavur. 
S.No.

Name of the isolates

Sampling Stations

\section{Pond 1 Pond 2 Pond 3 Pond 4 Pond 5}

\begin{tabular}{|c|c|c|c|c|c|c|}
\hline 1. & Microcystis aeruginosa Kütz & + & + & - & - & - \\
\hline 2. & Aphanothece microscopica Näg* & - & + & + & + & + \\
\hline 3. & Chroococcus turgidus (Kütz.)Näg & - & + & - & + & - \\
\hline 4. & Chroococcus minutus (Kütz.)Näg* & - & - & + & + & - \\
\hline 5. & Gloeocapsa stegophila (Itzigs.) Rabenh* & - & + & - & - & + \\
\hline 6. & Gloeothece samoensis Wille & - & - & + & - & - \\
\hline 7. & Synechococcus elongatus Näg & + & - & + & + & - \\
\hline 8. & Synechocystis aquatilis Sauv.* & - & + & + & + & + \\
\hline 9. & Myxosarcina concinna Printz & - & + & - & + & + \\
\hline 10. & Dermocarpa leibleinea (Reinsch)Born.et Thur. & - & - & - & + & - \\
\hline 11 . & Merismopedia glauca (Ehrenb.) Näg. & - & + & + & + & + \\
\hline 12. & Spirulina subsalsa Oerst.ex Gomont & - & - & + & + & - \\
\hline 13. & Spirulina labyrinthiformis (Menegh.) Gomont & + & + & + & + & - \\
\hline 14. & Spirulina meneghiniana Zanard. & + & - & + & - & - \\
\hline 15. & Oscillatoria curviceps Ag.ex Gomont* & - & + & - & - & - \\
\hline 16. & Oscillatoria subbrevis Schemidle* & + & + & + & + & + \\
\hline 17. & Oscillatoria pseudogeminata Schmid & - & + & + & - & - \\
\hline 18. & Oscillatoria tenuis Ag. Ex Gomont & + & + & - & - & - \\
\hline 19. & Oscillatoria earlei Gardner & - & - & + & + & + \\
\hline 20. & Oscillatoria formosa Bory ex Gomont & - & + & - & - & - \\
\hline 21. & Oscillatoria brevis (Kütz.) Gomont & - & + & + & - & - \\
\hline 22. & Oscillatoria boryana Bory ex Gomont & - & - & + & - & - \\
\hline 23. & Oscillatoria limnetica Lemm. & - & + & + & + & + \\
\hline 24. & Oscillatoria amphibia Ag.ex Gomont & - & + & + & - & - \\
\hline 25 . & Phormidium tenue (Menegh.) Gomont & - & + & + & + & + \\
\hline 26. & Phormidium corium (Ag.) Gomont & - & - & + & + & - \\
\hline 27. & Phormidium fragile (Menegh.) Gomont & - & + & + & - & - \\
\hline 28. & Phormidium molle (Kütz.)Gomont & - & + & - & - & - \\
\hline 29. & Lyngbya martensiana Menegh.ex Gomont & - & + & + & - & + \\
\hline 30. & Lyngbya ceylanica Wille & - & + & - & + & - \\
\hline 31. & Lyngbya allorgei Fremy & - & - & + & - & - \\
\hline 32. & Lyngbya lutea (Ag.) Gom. & - & - & + & - & - \\
\hline 33. & Schizothrix sp. & - & + & - & - & + \\
\hline 34. & Calothrix brevissima West,G.S. & - & - & + & + & - \\
\hline 35 . & Calothrix sp. & - & + & - & - & - \\
\hline 36. & Scytonema sp. & - & + & + & - & + \\
\hline 37. & Plectonema sp. & - & + & - & - & + \\
\hline 38. & Nostoc carneum Ag. ex Born. et Flah & - & - & + & + & - \\
\hline \multirow[t]{2}{*}{39.} & Anabaena sp. & - & - & + & - & - \\
\hline & Total number of species/genera & $6 / 4$ & $25 / 15$ & $26 / 14$ & $18 / 13$ & $13 / 11$ \\
\hline
\end{tabular}

Table 1. Diversity of Cyanobacteria in different fresh water ponds of Thanjavur. +: present; -: not recorded. Pond 1: Dabeerkulam; Pond 2; Mariyamman Kovil; Pond 3: Padithurai; Pond 4: Pulavarnatham; Pond 5: Sivalingam temple. Diversidad de cianobacterias 5 charcas de Thanjavur. +: present; -: not recorded. Charca 1: Dabeerkulam; Charca 2: Mariyamman Kovil; Charca 3: Padithurai; Charca 4: Pulavarnatham; Charca 5: templo de Sivalingam. 
around Thanjavur city with seasonal algal blooms.

Visible and planktonic samples were collected from various freshwater ponds in and around Thanjavur during June 2004, namely Pond 1 (Dabeerkulam), Pond 2 (Mariyamman Kovil), Pond 3 (Padithurai near Mariyamman Kovil), Pond 4 (Pulavarnatham) and Pond 5 (Sivalingam temple) (fig. 1) using forceps, knifes and plankton net (mesh size $42 \mu \mathrm{m})$. Water samples were also taken from each site for analyzing physico-chemical and biological parameters such as plankton, $\mathrm{pH}$, dissolved oxygen, net productivity, alkalinity, nitrate, nitrite, total phosphorous and inorganic phosphorus and by using standard methods (APHA, 1975).

The collected cyanobacterial samples were transferred to conical flasks with BG 11 medium (Rippka et al., 1979). Cyanobacterial specimens were identified using the publications of Geitler, 1932; Desikachary, 1959 and Starmach, 1966. Photomicrography was taken using Leitz Diaplan photomicrographic unit (Germany). The correlation co-efficient analysis was made between physico-chemical properties of water and total cyanobacterial species.

\section{RESULTS}

Totally 39 species belongs to 20 genera of cyanobacteria were recorded in all 5 ponds (tab. 1, figs. 2 to 15). Five species of the cyanobacteria viz., Synechocystis aquatilis, Aphanothece microscopica, Merismopedia glauca, Oscillatoria limnetica, and $O$. subrevis were common in all ponds except pond 1, where a massive bloom of Microcystis aeruginosa (fig. 2) was recorded. Maximum 26 species of 14 genera were recorded from Pond 3 followed by 25 species belonging from 15 genera, 18 species from 13 genera, 13 species from 11 genera and 6 species from 4 genera in Pond 2, Pond 4, Pond 5 and Pond 1 respectively (tab. 1). As per the diversity and abundance of cyanobacteria, the members of the family Oscillatoriaceae were dominating in most of the ponds surveyed. As many as five species namely Aphanothece microscopica, Synechocystis aquatilis, Merismopedia glauca, Oscillatoria limnetica and $O$. subbrevis were common in all the ponds surveyed except in Pond 1.

Physico-chemical analysis of water revealed that the $\mathrm{pH}$ range from 6.5 to 7.3 , dissolved oxygen from 0.8 to $1.4 \mathrm{mg} \mathrm{l}^{-1}$, net productivity from 0.4 to $0.6 \mathrm{mg} \mathrm{cm}^{3-1} \mathrm{l}^{-1}$, alkalinity (carbonate from 1.0 to $1.8 \mathrm{mg} \mathrm{l}^{-1}$ and bicarbonate from 25.6 to $45.0 \mathrm{mgl}^{-1}$ ), nitrate from 5.0 to $9.9 \mathrm{mg} \mathrm{l}^{-1}$, nitrite from 2.6 to $5.5 \mathrm{mg} \mathrm{l}^{-1}$, total phosphorous from 2.6 to $5.7 \mathrm{mg} \mathrm{l}^{-1}$ and inorganic phosphorus from 4.2 to $5.5 \mathrm{mg} \mathrm{l}^{-1}$ in all the ponds studied (tab. 2 ). The correlation co-efficient analysis of physico-chemical properties of water samples and total cyanobacterial species revealed that the significant positive correlation between Total Cyanobacterial Species (TCS) and dissolved oxygen $(\mathrm{r}=0.9803 ; \mathrm{p}<0.01)$, TCS and bicarbonate $(\mathrm{r}=$ $0.9928 ; \mathrm{p}<0.01)$ and TCS and carbonate $(\mathrm{r}=0.941 ; \mathrm{p}<0.05)($ tab. 3).

\section{DISCUSSION}

In any ecosystem, not a single species grows independently and indefinitely, because all the species are interlinked and has cyclic transformation of nutrients. The physicochemical changes in the environment may affect particular species and induce the growth and abundance of other species, which leads to the succession of several species in a course of time. In Pond 1, low diversity of cyanobacteria was attributed to 

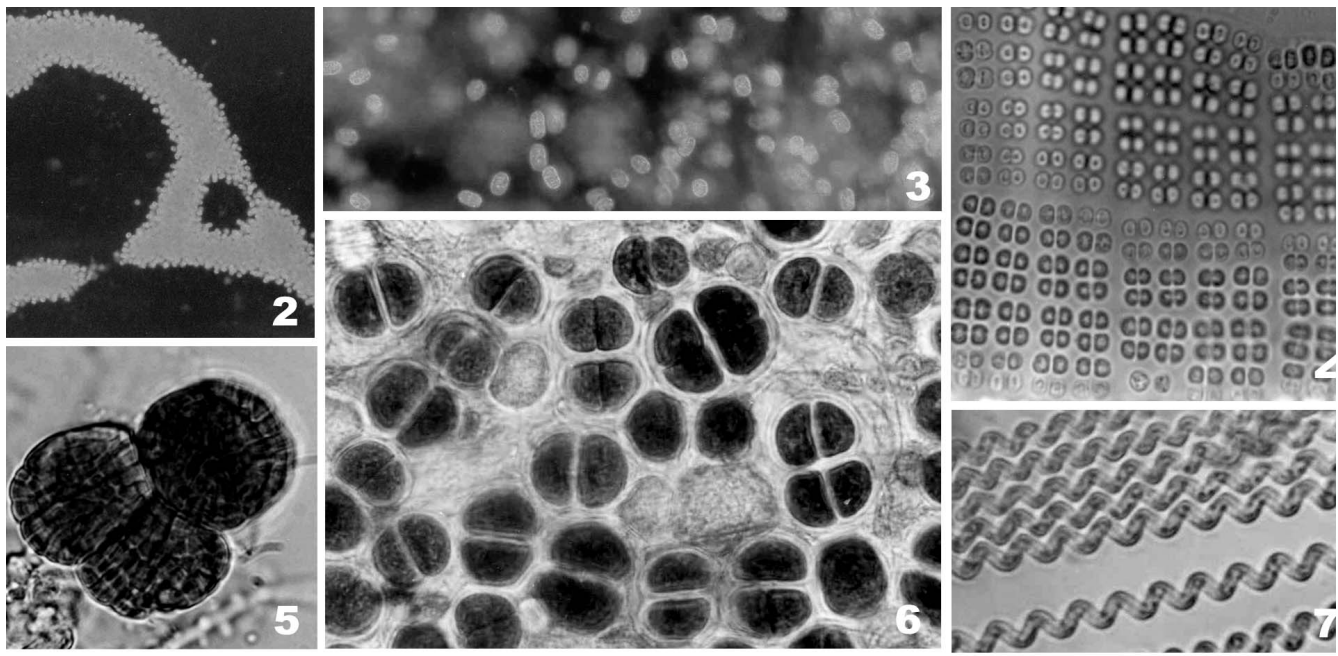

\section{0}

0.00000

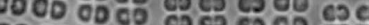

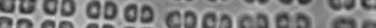
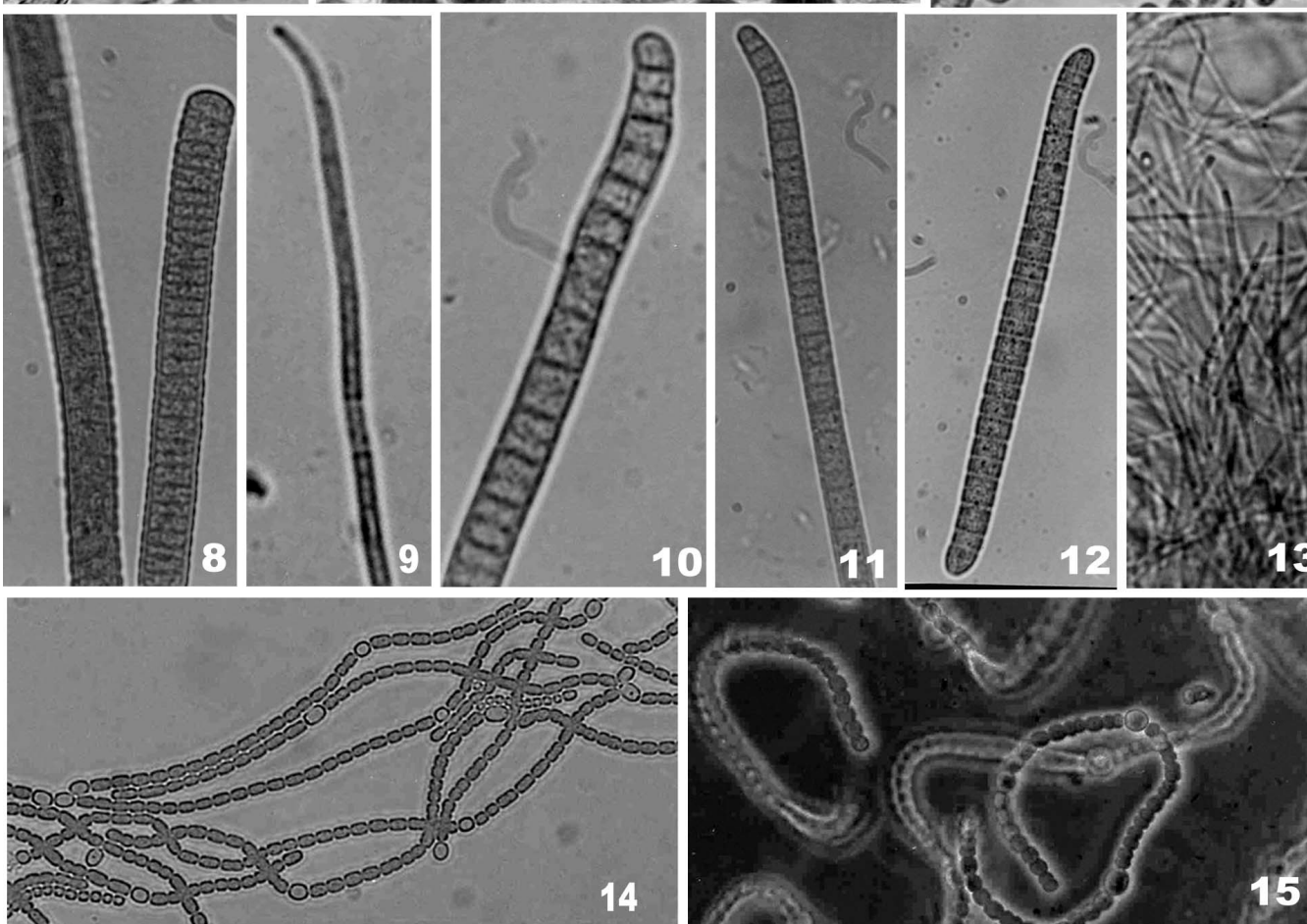

15

Figures 2-15 Microphotographs of some cyanobacteria isolated from different fresh water ponds of Thanjavur. 2: Microcystis aeruginosa; 3: Aphanothece microscopica; 4: Merismopedia glauca; 5: Myxosarcina concinna; 6: Chrococcus turgidus; 7: Spirulina meneghiniana; 8: Oscillatorai subbrevis; 9: Oscillatoria earlei; 10: Oscillatoria formosa; 11: Oscillatoria boryana;12: Oscillatoria tenuis; 13: Phormidium tenue; 14: Anabaena sp.; 15: Nostac carneum. Algunas de las cianobacterias aisladas en diferentes charcas de Thanjavur. 


\begin{tabular}{llcccrr}
\hline S.No. & \multicolumn{1}{c}{ Properties } & Pond 1 & Pond 2 & Pond 3 & Pond 4 & Pond5 \\
\hline 1. & pH & 7.3 & 6.5 & 6.7 & 6.5 & 6.8 \\
2. & Dissolved Oxygen $\left(\mathrm{mg} \mathrm{l}^{-1}\right)$ & 0.8 & 1.2 & 1.4 & 1.2 & 1.0 \\
3. & Net productivity $\left(\mathrm{mg} \mathrm{cm}^{3-1} \mathrm{l}^{-1}\right)$ & 0.6 & 0.6 & 0.4 & 0.4 & 0.4 \\
4. & Carbonate $\left(\mathrm{mg} \mathrm{l}^{-1}\right)$ & 1.0 & 1.8 & 1.6 & 1.4 & 1.2 \\
5. & Bicarbonate $\left(\mathrm{mg} \mathrm{l}^{-1}\right)$ & 25.6 & 39.0 & 45.0 & 36.6 & 33.4 \\
6. & Nitrate $\left(\mathrm{mg} \mathrm{l}^{-1}\right)$ & 9.9 & 5.0 & 9.6 & 8.7 & 6.8 \\
7. & Nitrite $\left(\mathrm{mg} \mathrm{l}^{-1}\right)$ & 3.0 & 5.5 & 4.2 & 4.0 & 2.6 \\
8. & Total phosphorus $\left(\mathrm{mg} \mathrm{l}^{-1}\right)$ & 4.4 & 2.6 & 5.0 & 4.9 & 5.7 \\
9. & Inorganic phosphorus $\left(\mathrm{mg} \mathrm{l}^{-1}\right)$ & 5.5 & 4.2 & 5.4 & 4.4 & 4.7 \\
\hline
\end{tabular}

Table 2. Physico-chemical properties of different pond water samples. Pond 1: Dabeerkulam; Pond 2: Mariyamman Kovil; Pond 3: Padithurai; Pond 4: Pulavarnatham; Pond 5: Sivalingam temple. Propiedades fisico-químicas de las diferentes charcas de Thanjavur. Charca 1: Dabeerkulam; Charca 2: Mariyamman Kovil; Charca 3: Padithurai; Charca 4: Pulavarnatham; Charca 5: templo de Sivalingam.

a massive bloom of Microcystis aeruginosa.

Low amount of dissolved oxygen $(0.8$ $\mathrm{mg} \mathrm{l}^{-1}$ ) in pond - 1, which had a significant effect in reducing the other cyanobacterial population (tab. 2). The similar type of results has also been reported (Subha \& Chandra, 2005; Pingale \& Deshmukh, 2005; Rani et al., 2005). Frankelin (1972) reported that Microcystis is one of the dominant organisms that is associated with almost permanent blooms in tropical freshwaters that are exposed to constant sunshine, warmth, and nutrients like phosphate, silicate, nitrate, $\mathrm{CO}_{2}$ and lime. Formation of cyanobacterial blooms in freshwater bodies is essentially due to buoyant nature of these organisms. Buoyancy of cyanobacteria is imported by the gas vacuoles which forms dense growth on the water surface in ponds, reservoirs and lakes and cause serious nuisance because of visual appearance, production of toxins (Carmichael, 1994) and unpleasant odour produced by substances such as geosmin (Juttner, 1987). Jeyaraman (1972) and Qasim (1972) reported that the dominance of cyanobacterial blooms in general, Trichodesmium bloom in particular may be due to two reasons: it may be a case of the superiority of the organism competing with the other organisms for the nutrient supply from the environment or it may be an instance where the metabolic products of the dominating species and creating unfavorable condition in the environment for the growth of other organisms.

Murphy et al. (1976) and Bailey \& Taub (1980) reported that the development of cyanobacterial blooms in any ecosystems, the siderophore mediated iron uptake in believed to be a contributing factor in their ability to dominate other microalage. Where as the other cyanobacterial forms that apparently cannot synthesize siderophore are able to utilize siderophore produced by other bacteria (Ferreira \& Straus, 1994). As also reported in other publications addressing the persistence and stability of various organisms in fresh water ecosystems (Duncan \& Blinn, 1989; Scarsbrook, 2002; Soininen \& Eloranta, 2004), cyanobacteria particularly forms their extreme blooms throughout the main part of the summer.

The crucial role of the physico-chemical parameters in the ecosystem on the 


\begin{tabular}{|c|c|c|c|c|c|c|c|c|c|c|}
\hline & pH & DO $N$ & Net Productivity & Carbonate & Bicarbonate & Nitrate & Nitrite & $\begin{array}{c}\text { Inorganic } \\
\text { phosphorus }\end{array}$ & $\begin{array}{c}\text { Total } \\
\text { Phosphorus }\end{array}$ & TCS \\
\hline pH & 1 & & & & & & & & & \\
\hline DO & -0.787 & 1 & & & & & & & & \\
\hline Net Productivity & 0.388 & -0.480 & 1 & & & & & & & \\
\hline Carbonate & -0.817 & 0.832 & $5.01 \mathrm{E}$ & 1 & & & & & & \\
\hline Bicarbonate & -0.764 & $0.986^{* *}$ & -0.461 & 0.847 & 1 & & & & & \\
\hline Nitrate & 0.532 & -0.121 & -0.270 & -0.559 & -0.202 & 1 & & & & \\
\hline Nitrite & -0.603 & 0.615 & 0.339 & 0.862 & 0.577 & -0.361 & 1 & & & \\
\hline Inorganic phosphorus & 0.867 & -0.391 & 0.074 & -0.641 & -0.377 & 0.777 & -0.511 & 1 & & \\
\hline Total Phosphorus & 0.209 & -0.031 & -0.815 & -0.547 & -0.040 & 0.595 & -0.768 & 0.425 & 1 & \\
\hline TCS & -0.806 & $0.980^{* *}$ & -0.379 & $0.904 *$ & $0.992 * *$ & -0.290 & 0.655 & -0.458 & -0.150 & 1 \\
\hline
\end{tabular}

Table 3. Correlation co-efficient analysis of physico-chemical properties of water and total cyanobacteria species; *: Significant at $0.5 \%$ level; **: Significant at $0.01 \%$ level. Coeficientes de correlación de las propiedades físico-químicas del agua y el total de especies de cianobacterias. * significativo al 05\%; **: significativo al 0,01\%.

distribution of algal community has been extensively analyzed in tropical and temperate freshwater ecosystems (Lund, 1965; Reynolds, 1984; Köhler, 1994). Chellappa et al. (2004) reported the collective dominance by the species of cyanobacteria was due to their capacity to grow in turbid water and low light intensity to maintain buoyancy and the capacity to grow exponentially in wet period in which nitrogenous nutrients were high. The daily water level fluctuations attributed to increase and decrease in phytoplankton species diversity. Pingale \& Deshmukh, (2005) identified 87 algal species belonging to 43 genera from Kalsubai-Ratangal, Ahmednagar. Subha \& Chandra (2005) studied the algal flora from temple tanks in and around the city of Chennai and reported 17 species of algae belonging to Cyanophyceae, Chlorophyceae, Bacillariophyceae and Euglenophyceae. Of the 39 species of cyanobacteria recorded in the present study, only 5 heterocystous cyanobacteria such as Calothric brevissima, Calothrix sp., Scytonema sp., Anabaena sp. and Nostoc carneum were recorded. Hoyslew \& Pearson, (1979) and Oren \& Shilo, (1979) reported that the high levels of sulfide content, and anaerobic conditions was believed to exclude the heterocystous forms. High levels of nitrogen source in the environment is also eliminating heterocystous forms, since nitrogen free media is commonly used for the isolation and purification of heterocystous cyanobacteria.

The significant positive correlation between the cyanobacterial diversity and micronutrients (zinc and nitrite) was observed and also reported by Govindasamy \& Azaraiah (1999). In the present study the significant positive correlation was observed between the Total Cyanobacterial Species (TCS) and dissolved oxygen $(r=0.9803$; $p<0.01)$, TCS and bicarbonate $(r=0.9928$; $\mathrm{p}<0.01)$ and TCS and carbonate $(\mathrm{r}=0.941$; $\mathrm{p}<0.05$ ). Hence the present study concluded inspite of the fact that the cyanobacteria are ubiquitous, their population dynamics are often influenced by the available nutrients and the physico-chemical conditions of the ecosystem.

ACKNOWLEDGEMENT. We thank Prof. G. Subaramanian, former Director and Prof. L. Uma, Director, National Facility for Marine Cyanobacteria, Bharathidasan University, Tiruchirappalli $-620 \quad 024$ for providing photomicrographic facilities. 


\section{REFERENCES}

APHA, -1975-Standard methods for the examination of water and wastewater $\left(14^{\text {th }}\right.$ edn.), American Public Health Association, Washington, D.C.

BAILEY, K.M. \& F.B. TAUB -1980- Effects of hydroxamate siderophores (strong Fe (III) chelators) on the growth of algae. Journal of Phycology 16: 334-339.

BOROWITZKA M.A. -1988- Vitamins and fine chemicals from Microalgae. In: Microalgal Biotechnology (Eds.) Borowitzka, M.A.and Borowitzka, L.J., Cambridge University Press. pp 153 - 196.

CARMICHAEL, W.W. -1994- The toxins of cyanobacteria. Science America 270: 78 - 86.

CHELLAPPA, S.L., I.R. MARINHO \& N.T. CHELLAPPA -2004- Freshwater phytoplankton assemblages and the bloom of toxic cyanophyceae of Campo Grande reservoir of Rio Grande do Norte State of Brazil. Indian Hydrobiology 7: 151 - 171.

DE, P.K. -1939- The role of Blue-green algae in nitrogen fixation in the rice fields. Proc. $R$. Soc. B., 127: $121-139$.

DESIKACHARY, T.V. -1959- Cyanophyta, Indian Council of Agricultural Research, New Delhi. 686 pp.

DUNCAN, S.W. \& , D.W. BLINN -1999Importance of physical variable on the seasonal dynamics of epilithic algae in a highly shaded canyon stream. Journal of Phycology 25: 455-461.

FERREIRA, F. \& N.A. STRAUS -1994- Iron deprivation in cyanobacteria. Journal of Applied Phycology 6: 199-210.

FRANKELIN, T. -1972- Blue-green algae of some tropical reservoirs of south India. In: Taxonomy and Biology of Blue-green algae, (Ed.) T.V. Desikachary, University of Madras. pp 442 - 447.

GEITLER, L. -1932-Cyanophyceae. In: L. Rabenhort's Kryptogamen Flora, Academische Veelagsgesellschaft Leipzig, pp. 1196.

GOVINDASAMY, C. \& J. AZARIAH -1999Seasonal variation of heavy metals in coastal water of the Coromandel Coast, Bay of Bengal, India, Indian Journal of Marine
Science 28: 249-256.

GUSTAFSON, K.R., J.H. CARDELLINA, R.W. FULLER, O.S. WEISLSON, R.F. KISER \& K.M. SNADER -1989- Antiviral sulfolipids from cyanobacteria (Blue-green algae). Journal of National Cancer Institute 81: 1254

HOWSLEY, R. \& H.W. PEARSONS -1979- pH dependent sulfide toxicity to oxygenic photosynthesis in cyanobacteria. FEMS Microbioogy Lette, 6: 287293.

JEYARAMAN, R. -1972- On the occurrence of blooms of blue-green algae associated oceanographic conditions in the northern Indian Ocean. In: Taxonomy and Biology of Blue-green algae, (Ed.) T.V. Desikachary, University of Madras. pp. 428 - 432.

JUTTNER, F. -1987- Volatile organic substances. In: The Cyanobacteria. (Eds.) Fay, P. and VanBaalen,C) Elsevier, Amsterdom, pp 453 $-469$.

KANNAIYAN, S. -1985- Algal biofertilizers for low land rice. Tamil Nadu Agricultural University, Coimbatore. pp. 14.

KÖHLER, J. -1994- Origin and succession of phytoplankton in a river-lake (Spree, Germany). Hydrobiologia 289: 73 - 83.

LUND, J.W.G. -1965- The ecology of freshwater phytoplankton. Biological Reviews 40: 231 293.

MITSUI, A., R. MURRAY, B. ENTENMAN, K. MIYAZAWA \& E. POLK -1981-Utilization of Marine blue-green algae and microalgae in warm water mariculture. In: Biosaline Research. A Look to the Future. (Ed.) San Pietro, Plenum Press. New York. 215 - 225.

MURPHY, T.P., D.R.S. LEAN \& C. NALEWAJKO -1976- Blue green algae: their excretion of iron selective chelators enables them to dominate other algae. Science 192: 900-902.

OREN, A. \& M. SHILO -1979-Anaerobic heterotropic dark metabolism in the cyanobacterium Oscillatoria limnetica sulfur respiration and lactate fermentation. Archives Microbiology 122: 77 - 84.

PINGALE, S.D. \& B.S. DESHMUKH -2005Some fresh water algae from Amphitheatre of Wilson Dam. Indian Hydrobiology 7: 97100.

PRABAHARAN, D. \& G. SUBRAMANIAN - 
1995- Hydrogen photoproduction by marine cyanobacterium Dichothrix bauriana BDU 40481. Physiology and Molecular Biology of Plants 1: 45 - 57.

QASIM, S.Z. -1972- Some observations in Trichodesmium blooms. In: Taxonomy and Biology of Blue-green algae, (Ed.) T.V. Desikachary, University of Madras. pp 433 438.

RAJAKUMAR, N. -2004-A review on the quantum of phytoplanktonic primary production of a polluted freshwater pond. Indian Hydrobiology 7: 61 - 65.

RANI, G., K. INDHUMATHY \& K. SOFIA REVATHI -2005- Water characterization and fresh water algae of Chitlapakkam. Indian Hydrobiology 7: 143-146.

REYNOLDS, C.S. -1984- The Ecology of Freshwater phytoplankton. Cambridge University Press, Cambridge, UK. 384pp.

RIPPKA, R., J. DERUELLES, J.B WATERBURY, M. HERDMAN \& R.Y. STANIER -1979- Generic assignments, strain histories and properties of pure cultures of cyanobacteria. Journal of Geneneral Microbiology 111: 1 - 61.

SCARSBROOK, M.R. -2002- Persistence and stability of lotic invertebrate communities in New Zeland. Freshwater Biology 47: 417431.

SOININEN, J. \& P. ELORANTA -2004- Seasonal persistence and stability of diatom communities in rivers: are there habitat specific differences? European Journal of Phycology 39: 153-160.

SRIVASTAVA, P.N. \& B.R. ODHWANI -1992Algae from the inland salt pans. Journal of
Indian Botanical Society 71: 23-27.

STARMACH, K. -1966- Cyanophyta - Since. Galucophyta - Gluokofity. Flora Slodowodkan Polsi, Tom 2. Warszawa, 800 pp.

SUBBARAMAIAH, K. -1972- The biology of blue-green algae of Sambhar lake salt works. Symposium of the Taxonomy and Biology of Blue-Green Algae, Madras. (ed. Desikachary, T.V.), pp. 439-441.

SUBHA, T.S. \& S. CHANDRA -2005- Temple tanks, their status and algal biodiversity. Indian Hydrobiology 7: 123-127

SUBRAMANIAN, G. \& L. UMA -1996Cyanobacteria in pollution control. Journal of Science and Industrial Research 55: 685 692.

THAJUDDIN, N. \& G. SUBRAMANIAN -1992Survey of cyanobacterial flora of the southern east coast of India. Botanica Marina 35: 305 $-314$.

THAJUDDIN, N., A. NAGASATHYA, R. CHELLADEVI \& L. SARAVANAN -2002Biodiversity of cyanobacteria in different salt pans of Pudukkotai District, Tamilnadu. Seaweed Research and Utilization 24: 1 - 11.

THAJUDDIN, N. \& G. SUBRAMANIAN -2005Cyanobacterial BNiodiversity and potential application in Biotechnology. Current Science 89(1): 47-57.

VENKATARAMAN, G.S. -1981- Blue-green algae for rice production. FAO Soil Bulletins 16: $33-42$.

VENKATARAMAN, L.V. -1983- A Monograph on Spirulina platensis - Biotechnology and application. Department of Science and Technology, New Delhi. 